\title{
Ultrastructure of $\beta$-Cells during the Dynamic Response to Glucose and Tolbutamide in vitro*
}

\author{
J.C. Lee, G.M. Grodsky, L.L. Bennett, D. F. Syrth-KyLI and L. Craw
}

Departments of Pathology and Physiology, and the Metabolic Unit for Research, University of California School of Medicine, San Francisco, California, USA

Received: July 29, 1970

Summary. Ultrastructural changes in $\beta$ cells of the isolated perfused rat pancreas were observed during the dynamic response to glucose and tolbutamide. Evidence of granule secretion into the extracellular space by emiocytosis was noted during the first $60 \mathrm{sec}$ of glucose stimulation, but not thereafter nor at any time during tolbutamide stimulation. Packaging of granules within the Golgi apparatus was apparent after $60 \mathrm{~min}$ of glucose injection, but not in the case of tolbutamide. These findings support the concept that glucose initially stimulates the release of a small labile pool of preformed insulin, while continued administration stimulates Golgi packaging activity and the provision of additional insulin for the secretory process. High tolbutamide alone, in contrast increases the Golgi complex, coated vesicles, multivesicular bodies and cytosegresomes. Thus it may stimulate packaging without insulin provision, or alternatively, increase lysosomal degradative processes.

Ultrastructure des cellules $\beta$ au cours de la réponse dynamique au glucose et au tolbutamide in vitro

Résumé. Des modifications ultrastructurales dans les cellules $\beta$ du pancréas de rat isolé et perfusé ont été observées au cours de la réponse dynamique au glucose et au tolbutamide. On a noté une sécrétion granulaire évidente dans l'espace extracellulaire par émiocytose au cours des 60 premières secondes de stimulation par le glucose, mais non après et à aucun moment pendant la stimulation par le tolbutamide. Des amas de granules à l'intérieur de l'appareil de Golgi étaient apparents après 60 minutes d'injection de glucose, mais non dans le cas d'injection de tolbutamide. - Ces résultats renforcent l'idée que le glucose stimule initialement la libération d'un petit pool instable d'insuline préformée, tandis que l'administration continue stimule l'activité de stockage de l'appareil de Golgi et la provision d'insuline supplémen- taire pour le processus de sécrétion. Par contre, le tolbutamide seul à forte concentration, augmente le complexe de Golgi, les vésicules à membrane hérissée (coated vesicles), les corps multivésiculaires et les cytosegresomes. Il peut ainsi stimuler lo stockage sans provision d'insuline, ou alternativement, augmenter le processus lysosomal de dégradation.

Ultrastruktur der B-Zellen während der dynamischen Reaktion auf Glucose und Tolbutamid in vitro

Zusammenfassung. Ultrastructurelle Veränderungen in den B-Zellen von isoliertem perfundierten Rattenpancreas wurden während der dynamischen Realztion auf Glucose und Tolbutamid beobachtet. Augenscheinlich erfolg't eine Granula-Sekretion in den extracellulären Raum durch Emiocytose während der ersten 60 sec der Glucose-Stimulation, aber nicht danach, und auch nicht zu irgendeiner Zeit während der Tolbutamid-Stimulation. Dichtes Zusammenlagern von Granula innerhalb des Golgi-Apparates trat offensichtlich nach 60 min nach der Glucoseinjektion ein, aber nicht im Fall des Tolbutamid. - Diese Befunde unterstützen die Annahme, daß die Glucose im Anfang die Abgabe eines kleinen labilen pools von präformierten Insulin anregt, während fortgesetzte Verabreichung die Aktivität der dichten Anlagerung am Golgi-Apparat und die Bereitstellung von zusätzlichem Insulin für den Sekretionsprozeß stimuliert. Hohe Dosen von Tolbutamid allein vermehren andererseits den Golgi-Komplex, die bedeckten Bläschen, die multivesilkulären Körper und die Cytosegresomen. Insofern könnte Tolbutamid die Anreicherung ohne Bereitstellung von Insulin stimulieren oder aber lysosomale Degradationsprozesse vermehren.

Key-words: Tolbutamide stimulation, glucose stimulation, $\beta$-cell ultrastructure, insulin secretion, perfused rat pancreas.
Ultrastructural visualization of insulin synthesis and secretion by $\beta$-cells of the islets of Langerhans in previous studies has been hampered by methods of tissue fixation that do not adequately preserve the insulin granules $[2,16,1,21,18,27]$. Consequently, conflicting opinions exist concerning the origin of $\beta$ granules and their method of secretion in response to glucose stimulation.

Studies in vitro using the perfused rat pancreas have demonstrated that the secretion of insulin occurs within $30 \mathrm{sec}$ in response to stimulation by glucose or tolbutamide [10]. Despite constant stimulation by either glucose or tolbutamide, this secretion is abrupt, with a rapid rise and fall within $3 \mathrm{~min}[11,4]$. However, continued infusion of glucose induces a second increase in the rate of insulin release, whereas continued infusion of tolbutamide does not [4, 12]. Studies employing

* Supported in part by U.S. Public Health Service Grants AM 11182 and AM 01410. puromycin indicate that these two phases of insulin release represent different, though related, $\beta$-cell phenomena $[11,4]$.

The present experiments were designed for ultrastructural visualization of these different phases of insulin secretion occurring in the perfused rat pancreas in response to glucose and tolbutamide stimulation. This system has the advantage of prompt tissue fixation by perfusion of fixative at specific timed intervals during secretory stimulation. The morphologic changes observed can then be correlated with the different phases of insulin release occurring at almost the same instant.

\section{Materials and Methods}

The perfused pancreatic system in vitro of the fasted rat has been described in detail $[10,4,5]$. Briefly, this consists of complete surgical isolation of the entire pancreas with its arterial and venous supply 
intact; the pancreas with the adjacent spleen, stomach and part of the duodenum is then transferred to the perfusion apparatus. Each individual preparation was perfused with a completely synthetic fluid consisting of $4 \%$ human albumin (Cutter Laboratories, Berkeley, Calif.) in bicarbonate phosphate buffer. The perfusate was introduced into the celiac axis at a flow rate of 10-12 $\mathrm{ml}$ per minute, and glucose or tolbutamide was added to the perfusate to produce a peak concentration of $300 \mathrm{mg} / 100 \mathrm{ml}$ or $30 \mathrm{mg} / 100 \mathrm{ml}$, respectively.

Thirty-nine pancreatic preparations were used in this study. Tissue samples were collected for examination after initiation of continuous glucose stimulation at the following time intervals: $30 \mathrm{sec}, 3^{1} ; 45$ sec, 2 ; $60 \mathrm{sec}, 3 ; 120 \mathrm{sec}, 3$; and $60 \mathrm{~min}, 4$. Tissue samples were collected for examination after initiation of continuous tolbutamide stimulation at the following time intervals: $30 \mathrm{sec}, 3 ; 45 \mathrm{sec}, 2 ; 60 \mathrm{sec}, 6$; and $60 \mathrm{~min}, 8$. Five preparations, perfused without added glucose or tolbutamide for $60 \mathrm{~min}$, served as controls.

Tissue specimens were fixed by injecting $3 \%$ distilled glutaraldehyde buffered to $\mathrm{pH} 7.4$ with $0.1 \mathrm{M}$ sodium cacodylate through the perfusion apparatus at the specific time intervals [24]. Immediately afterward, a small fragment from the tail portion of each rat was removed, minced into cubic millimeter pieces, and placed in a drop of fixative. Fixation was accomplished overnight at $4^{\circ} \mathrm{C}$, followed by $90 \mathrm{~min}$ postfixation in $1 \% \mathrm{OsO}_{4}$ [3]. Specimens were then dehydrated in graded alcohols and embedded in epoxy resin [20]. The islets were subsequently localized with toluidine blue staining of thick sections. After lead citrate and uranyl acetate staining, ultrathin sections were photographed with a Siemen's Elmiskop IA with a $35-\mu$ objective aperture.

\section{Results}

Fig. 1 presents the results obtained when glucose or tolbutamide was perfused at constant concentration. These experiments were concurrent with the electron microscopic studies and illustrate the multiphasic patterns of insulin secretion previously reported $[11,4$, $12,5]$.

Controls. The ultrastructure of islet cells in the rat has been documented [16]. Changes produced by perfusion of albumin buffer for $60 \mathrm{~min}$ consisted only of widening of intercellular spaces, which occurred in most but not all preparations (Fig. 2); otherwise all cellular components maintained a normal morphology. All $\beta$-cells contained abundant insulin granules, many aligned along the cell plasma membrane. Evidence of granule packaging was not found in the Golgi cisternae of control preparations.

Glucose stimulation. Thirty seconds after glucose stimulation, $\beta$-cells appeared identical to those of control preparations and there was no evidence of secre-

1 Indicates number of pancreatic preparations used at each specified time interval. tory activity. At $45 \mathrm{sec}$, however, dense material was occasionally observed outside the cell (Fig. 3), although this occurred infrequently. At $60 \mathrm{sec}$ (Fig. 4), many dense granule-like fragments could be found in the intercellular spaces; by 120 sec, these were no longer visible. Examination of the Golgi apparatus at these time intervals failed to reveal granule packaging, and in this respect the glucose-stimulated preparations resembled the controls. No morphologic changes in the rough-surfaced endoplasmic reticulum were noted. The total granule content of $\beta$-cells at all time intervals was visibly the same as in control specimens, indicating that only a small percentage of the total insulin granules had been discharged.
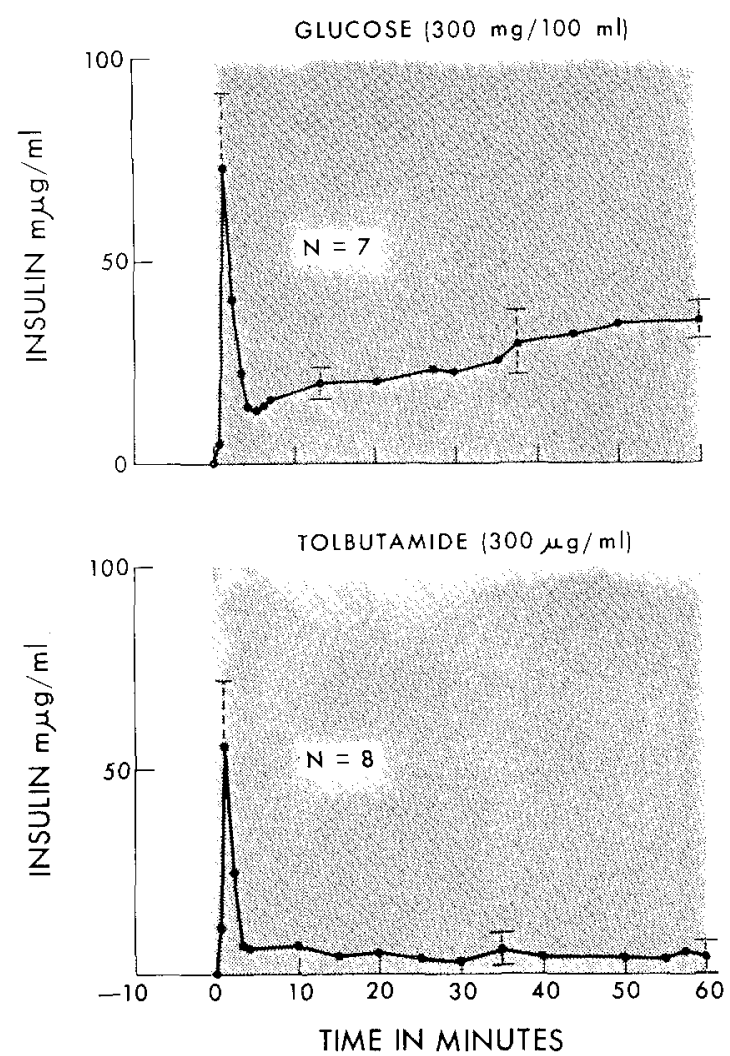

Fig. 1. Effect of continuous perfusion of glucose or tolbutamide on secretion of insulin. Experimental design differs from that previously published [4] in that a prior 2-min stimulation at (-) 4 min was eliminated. $=$ S.E.

After $60 \mathrm{~min}$ of glucose stimulation, granule formation within Golgi cisternae was easily visualized (Fig. 5). No other morphologic changes were evident, and the granule content of individual $\beta$-cells remained visibly unaltered.

Tolbutamide stimulation. The preparations observed at 30,45 , and $60 \mathrm{sec}$ revealed no difference from controls. Secretion of dense granule-like material was never observed. However, after $60 \mathrm{~min}$, the average total granule content of individual $\beta$-cells appeared to be 


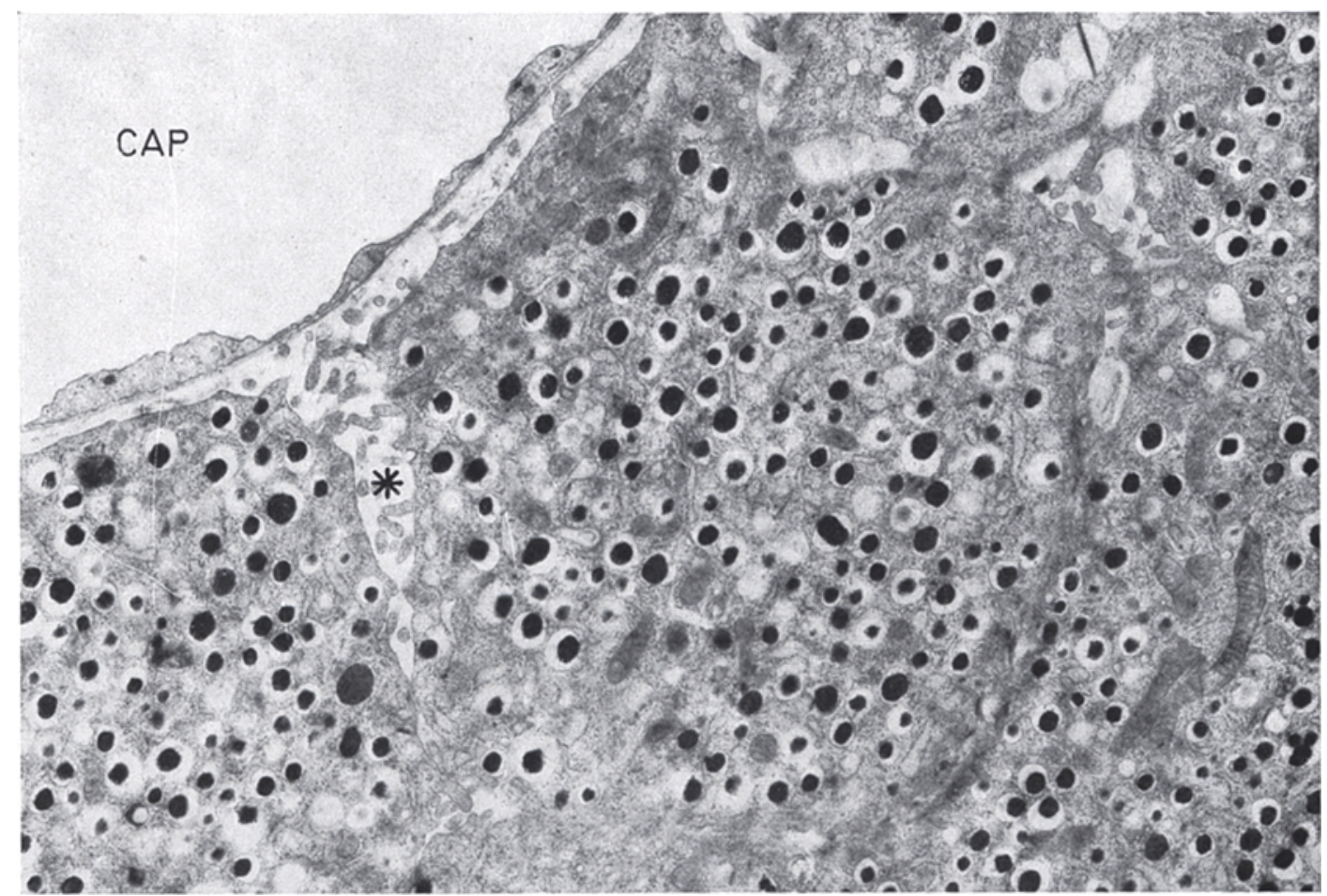

Fig 2. Islet cells from a control preparation after $75 \mathrm{~min}$ of perfusion without added glucose or tolbutamide to demonstrate widening of intercellular spaces $(*)$ foud in all specimens. CAP $=$ capillary $(\times 8500)$

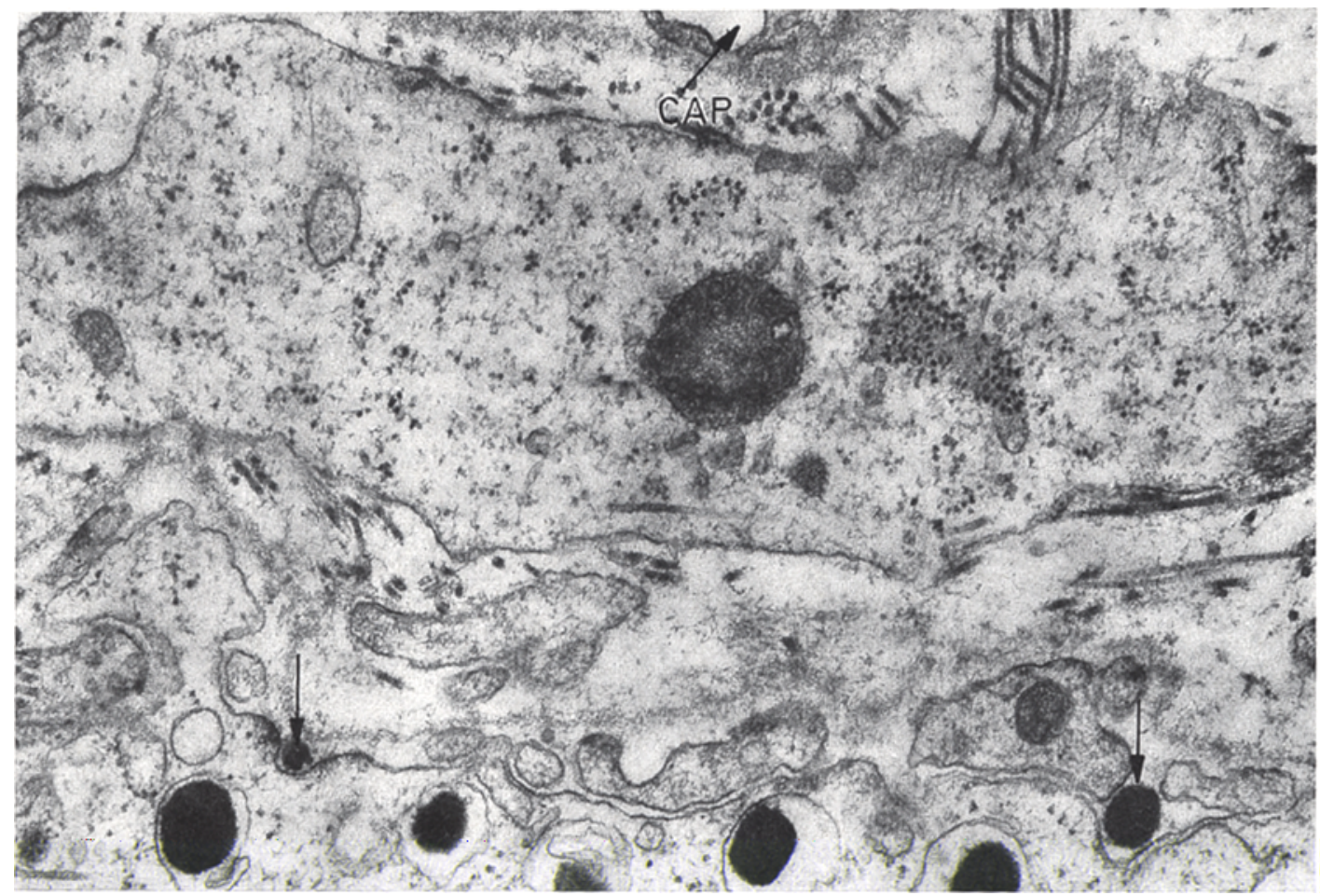

Fig. 3. Forty-five seconds after glucose stimulation, $\beta$ granules appear just outside the plasma membrane within small invaginations (arrows). CAP $=$ capillary $(\times 36550)$ 


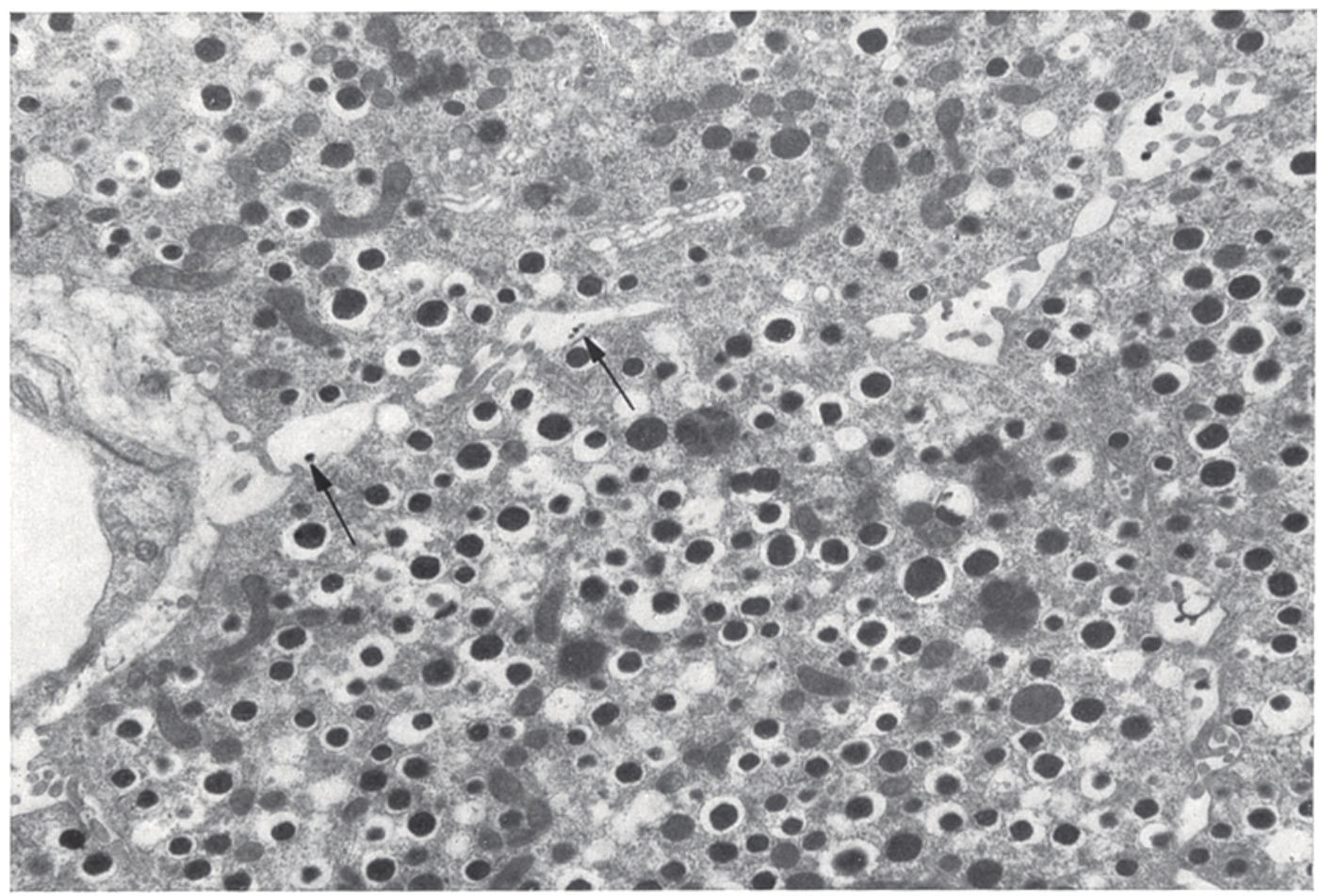

Fig. 4. After $60 \mathrm{sec}$ of glucose perfusion, there are multiple granules within intercellular spaces (arrows) ( $\times 14700)$

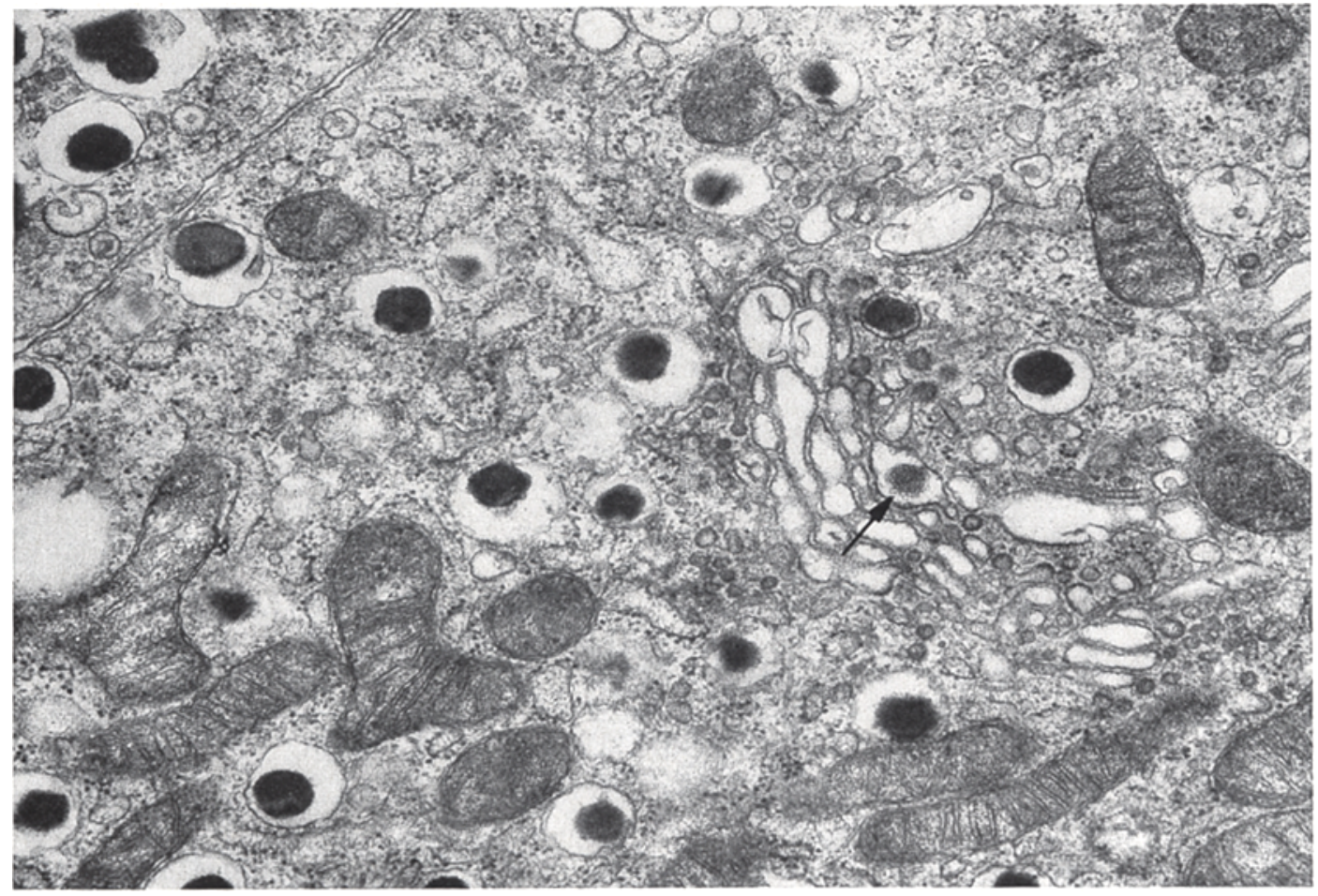

Fig. 5. Granule formation within Golgi cisternae (arrow) of $\beta$-cells are easily found after 75 min of glucose stimulation $(\times 28000)$ 


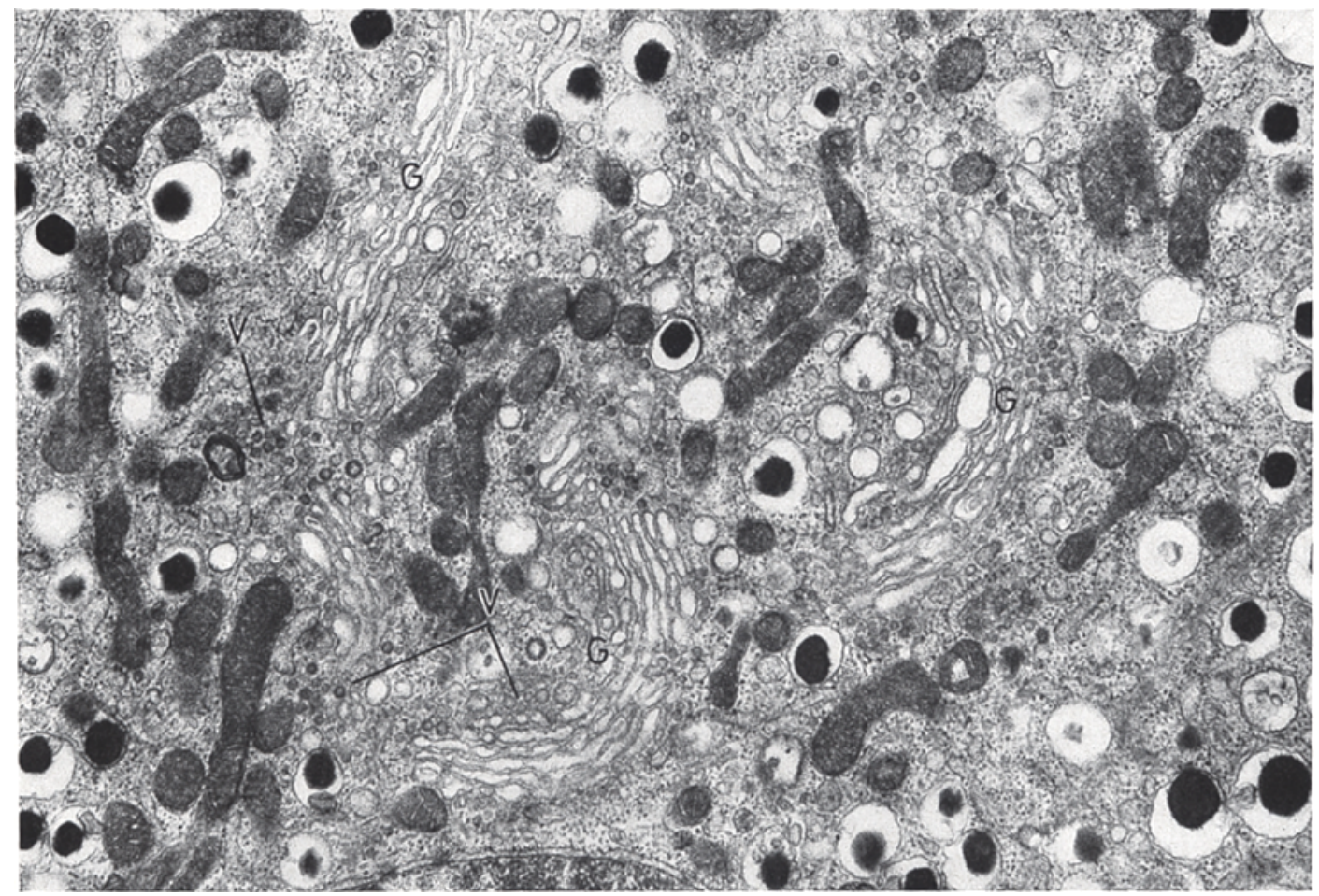

Fig. 6. After 75 min of tolbutamide stimulation, the Golgi apparatus (G) occupies a large portion of $\beta$-cell cytoplasm. Many small coated vesicles (V) are associated with Golgi membranes ( $\times 20580)$

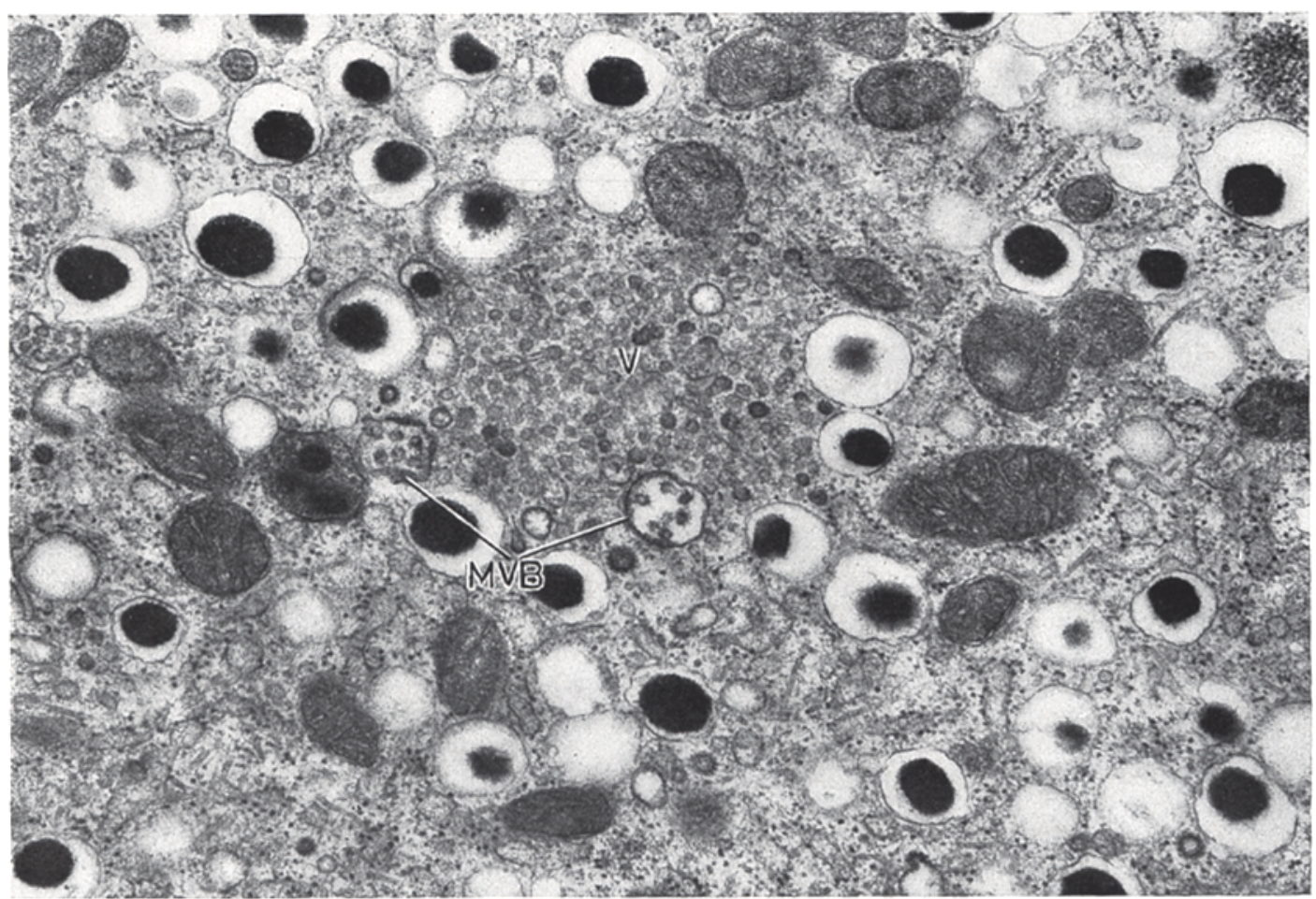

Fig. 7. Small coated vesicles (V) frequently form small clusters and are often associated with multivesicular bodies (MVB), the contents of which closely resemble the coated vesicle. Seventy-five minutes of tolbutamide stimulation $(X 30330)$ 
reduced. In contrast to results of glucose stimulation, morphologic evidence of granule formation in Golgi cisternae was not found. However, the Golgi apparatus seemed unusually large and occupied a much greater portion of the cytoplasm than was the case in controls (Fig. 6). A marked increase in the number of small coated vesicles, frequently forming small clusters, was observed in the convexity of the Golgi apparatus and elsewhere in the cytoplasm (Figs. 6 and 7). Associated with these were occasional multivesicular bodies, which contained small coated vesicles apparently identical to those of the clusters (Fig. 8). of the entire insulin content of the intact pancreas [11, $4,12,5]$. Consequently the chances of visualizing granule discharge are slim. We were able to observe definite discharge of granule-like material only at the time of peak secretion $(60 \mathrm{sec})$. Similar extracellular granulelike material was observed by Lacy [17] in glucosetreated rats, but not by Findlay et al. [8] with preparations in vitro. Possibly the rapid fixation obtained in our preparations in vitro permitted the more frequent visualization.

The secretory process in the $\beta$-cell at this stage is apparently similar to that in other endocrine cells -

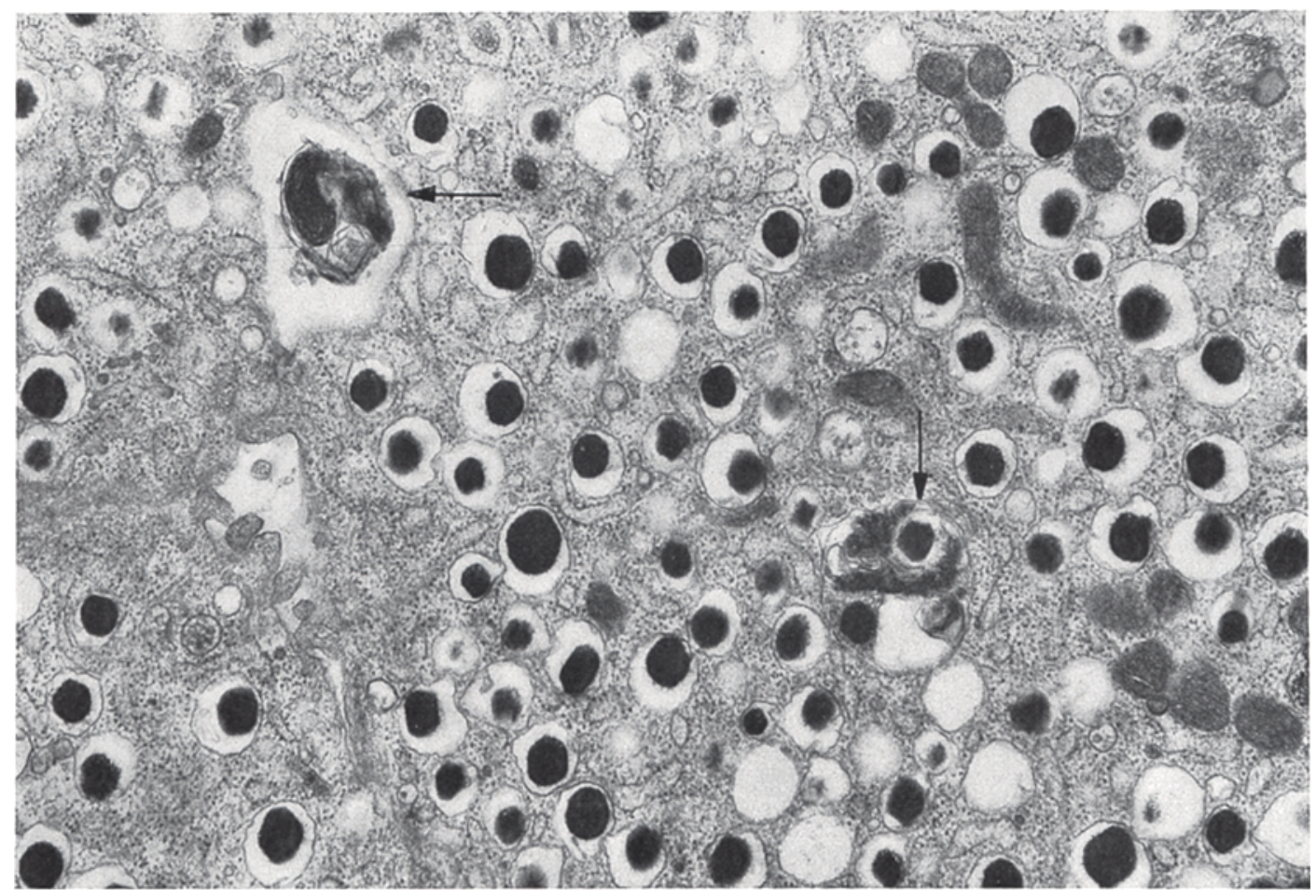

Fig. 8. Cytosegresomes (arrows) were frequently noted after tolbutamide stimulation and often contained membrane whorls and recognizable cellular organelles $(\times 21000)$

The appearance of many cytosegresomes [6], often containing recogniza ble cellular organelles and granules was another notable feature.

\section{Discussion}

Previous studies involving the isolated perfused rat pancreas have demonstrated that the release of insulin in response to constant glucose stimulation occurs in $30 \mathrm{sec}$, reaches a peak at approximately $60-90 \mathrm{sec}$, but rapidly decreases within a few minutes [10]. Thereafter, with maintained glucose stimulation, there is a second, gradually increasing rate of insulin release that continues for at least $1 \mathrm{~h}$ [4]. During the initial release period, total secreted insulin amounts to only $1-3 \%$ through emiocytosis $[17,7]$. The observation of extracellular granular material also suggests that granules do not have to become soluble within the cell cytoplasm to be secreted.

These observations are consistent with the previous suggestion that the initial release represents the secretion of preformed insulin, perhaps from a small, labile compartment $[11,4,12]$. With prolonged glucose stimulation and corresponding with the second increase of insulin secretion rate, there was morphologic evidence of the formation of new insulin granules in the Golgi apparatus. This evidence of increased insulin packaging, stimulated by glucose, supports the mathematical model recently proposed $[12,13]$, in which the second rise in insulin secretion rate was ascribed to the ability 
of glucose to provide more insulin for eventual secretion. The source of this insulin is unknown. Previous studies using leucine- ${ }^{3} \mathrm{H}$ demonstrated that glucose can increase the de novo synthesis of insulin from amino acids $[26,15]$. However, the second phase of glucosestimulated insulin release is not completely blocked by puromycin [4]. Our current findings at $60 \mathrm{~min}$ revealed little decrease in visible cytoplasmic granules at a time when an equivalent of $20-40 \%$ of the pancreatic insulin content had been secreted [4]. This indicates a net increase in granular insulin, though visual estimates of the degree of granulation are subject to gross error. We emphasize that our observations support the possibility that glucose acts to increase insulin availability by directly stimulating the Golgi packaging apparatus or by increasing the conversion of insulin from proinsulins, as well as directly affecting de novo synthesis from amino acids. Extracellular granules were not seen during the provisionary phase at $60 \mathrm{~min}$ even though insulin secretion had returned to rates comparable with those at 60 sec. Model analysis $[12,13]$ suggests that there may be a preferential release of the newly formed or newly packaged insulin; possibly the insulin release at $60 \mathrm{~min}$ was from immature granules containing less dense material.

We never observed granule formation within the rough-surfaced endoplasmic reticulum [2]. Moreover, granule formation in the Golgi apparatus was not noted. after prolonged tolbutamide stimulation, again agreeing with previous data reporting the failure of this agent to cause secondary provision of insulin $[4,12,13]$ or stimulation of insulin synthesis [26]. Enlargement of the Golgi apparatus and the appearance of many coated vesicles and multivesicular bodies within $\beta$-cell cytoplasm following tolbutamide stimulation may be manifestations of cell injury. These multivesicular bodies may be lysosomes, since they have been found by other investigators to contain acid phosphatase [22, 14, 9]. Evidence indicates that the Golgi apparatus is the source of lysosomes [25].

Cytosegresomes [6] also appeared in the cytoplasm of $\beta$-cells after tolbutamide administration but were seldom observed in controls. Of particular interest is the possibility that tolbutamide exerts a direct effect on Golgi packaging activity, but, in contrast to glucose, does not stimulate the provision of the insulin to be packaged. This activity could relate to the cytotrophic action noted after prolonged treatment of animals with the sulphonylureas [19].

The previous demonstration of a multiphasic insulin release from the pancreas during constant stimulation by glucose $[4,11,12]$ has been confirmed in vivo by others $[28,23]$. The suggestion that the pattern of response reflects a series of different time-related phenomena all contributing to the ultimate rate of insulin secretion $[11,4,12,13]$ is further substantiated by the current electron microscopic evidence that different organelles are affected during the different phases of the stimulatory period.
Addendum added in proof. During publication processing of this manuscript, an inhibition of insulin synthesis by the specific conditions of high concentration of tolbutamide with low glucose was reported (Tanese, T., Lazarus, N.R., Devrim, S., Recant, L.: Synthesis and release of proinsulin and insulin by isolated rat islets of Langerhans, J. Clin. Invest. 49, 1394-1404 (1970)). These studies are consistent with our observation of increased lysosomal activity under similar conditions. The possibility of a qualitative change in the action of moderate concentrations of sulphonylureas in the presence of glucose is being investigated.

\section{References}

1. Amsterdam, A., Schramm, M. : Rapid release of the zymogen granule protein by osmium tetroxide and its retention during fixation by glutaraldehyde. J. cell. Biol. 29, 199-207 (1966).

2. Bencosme, S.A., Martinez-Palomo, A.: Formation of secretory granules in pancreatic islet $\beta$-cells of cortisone-treated rabbits. Lab. Invest. 18, 746-756 (1968).

3. Caulfield, J.B.: Effects of varying the vehicle for $\mathrm{OsO}_{4}$ in tissue fixation. J. biophys. biochem. Cytol. 3, $827-830$ (1957).

4. Curry, D. L., Bennett, L. L., Grodsky, G.M. : Dynamics of insulin secretion by the perfused rat pancreas. Endocrinology 83, 572-584 (1968).

5. - - - Requirement for calcium ion in insulin secre. tion by the perfused rat pancreas. Amer. J. Physiol. 214, $174-178$ (1968).

6. Ericsson, J.L.E., Trump, B.F., Weibel, J.: Electron microscopic studies of the proximal tubule of the rat kidney. II. Cytosegresomes and cytosomes: Their relationship to each other and to the lysosome concept. Lab. Invest. 14, 1341-1365 (1965).

7. Farquhar, M.G.: Fine structure and function in capillaries of the anterior pituitary gland. Angiology 12, 270-292 (1961).

8. Findlay, J.A., Gill, J.R., Trvine, G., Lever, J.D., Randle, P.J.: Cytology of $\beta$-cells in rabbit pancreas pieces incubated in vitro; effects of glucose and tolbutamide. Diabetologia 4, 150-160 (1968).

9. Friend, D.S.: Cytochemical staining of multivesicular body and Golgi vesicles. J. cell Biol. 41, 269-279 (1969).

10. Grodsky, G.M., Bennett, L.L., Smith, D.F., Schmid, F.G.: Effect of pulse administration of glucose or glucagon on insulin secretion in vitro. Metabolism 16, 222-233 (1967).

11. - - Smith, D., Nemechek, K.: The effect of tolbutamide and glucose on the timed release of insulin from the isolated perfused pancreas. In: Tolbutamide after Ten Years. International Congress Series, no. 149, Excerpta Medica Foundation, Amsterdam, New York (1967).

12. - - Smith, D.F., Schmid, F.G.: In vitro studies suggesting a two-compartmental model for insulin secretion. The Islet Symposium (Umea, Sweden). In press $(1970)$.

13. - Landau, H., Curry, D., Bennett, L.: A two-compartmental model for insulin secretion. In: Early Diabetes, pp. 45-50. New York and London: Academic Press 1970.

14. Holtzman, E., Novikoff, A.B., Villaverde, H.: Lysosomes and GERL in normal and chromatolytic neurons of the rat ganglion nodosum. J. cell Biol. 33, $419-435$ (1967).

15. Howell, S.L., Taylor, K.W.: The secretion of newly synthesized insulin in vitro. Biochem. J. 102, 922-927 (1967). 
16. Lacy, P.E.: Electron microscopy of the normal islets of Langerhans. Diabetes 6, 498-507 (1957).

17. - Pancreatic beta cell. In: Ciba Foundation colloquia on endocrinology, Vol. 15, Aetiology of diabetes mellitus and its complications. London: J. \& A. Churchill, Ltd. 1964.

18. Lazarus, S.S., Shapiro, S.H., Volk, B.W.: Morphology of pancreatic $\beta$-cell secretion in neonatal rabbits. Lab. Invest. 16, 330-341 (1967).

19. Loubatieres, A.: Physiologie et pharmacodynamie de certains dérivés sulfamidés hypoglycémiants. Contribution a l'étude des substances synthétiques à tropisme endocrinien. Thèse Doct. ès-sciences Naturelles, Montpellier, N. 86, 93 pp., 1 er juin 1946.(Causse, Graille et Casteluan imprimeurs, Montpellier).

20. Luft, J.H.: Improvements in epoxy resin ombedding methods. J. biophys. biochem. Cytol. 9, 409-414 (1961).

21. Meyer, J., Bencosme, S.A.: The fine structure of normal rabbit pancreatic islet cells. Rev. canad. Biol. 24, $179-205(1965)$.

22. Novikoff, A.B., Essner, E., Quintana, N.: Golgi apparatus and lysosomes. Fed. Proc. 23, 1010-1022 (1964).

23. Porte, D., Jr.: Regulation of insulin secretion in vivo by glucose. III International Congress of Endocrinology, Excerpta Medica Foundation, International Congress Series (in press).

24. Sabatini, D.D., Bensch, K., Barrnett, R.J.: Cytochemistry and electron microscopy. The preservation of cellular ultrastructure and enzymatic activity by aldehyde fixation. J. cell Biol. 17, 19-58 (1963).

25. Smith, R.E., Farquhar, M.G.: Lysosome function in the regulation of the secretory process in cells of the anterior pituitary gland. J. cell Biol. 31, 319-347 (1966).

26. Taylor, K.W.: The biosynthesis of insulin in vitro. Diabetologia 4, 179 (1968).

27. Volk, B.W., Lazarus, S.S., Wellman, K.F. : Beta cell structure in latent and chronic diabetes of the rabbit. Diabetes 14, 792-804 (1965).

28. Waddell, R.W., Beck, J. C., Dupre, J.: Biphasic insulin secretory response to intravenous arginine in man. Diabetes 18 (Suppl. 1), 375 (1969).

Dr. John C. Lee

Department of Pathology

University of California

School of Medicine

San Franeisco, California 94122/USA 